\title{
エゾライチョウの人工飼料と摂食量
}

\author{
藤巻裕蔵・宮沢由香子・笹岡久美子 \\ 帯広畜産大学野生動物管理研究室
}

\section{Diet of Hazel Grouse and Diet Intake in Captivity}

\author{
Yuzo Fujimaki, Yukako Miyazawa and Kumiko Sasaoka \\ Laboratory of Wildlife Ecology, Obihiro University of Agriculture \\ and Veterinary Medicine, Inada, Obihiro 080
}

The diet intake of Hazel Grouses Tetrastes bonasia adults was investigated in captivity in 1988 and from 1991 to 1993 . Birds were fed on a mixture of commercial poultry rations and pet food with a supplement of fish meal from April to September. In addition, fibrous diets (Taraxacum officinale or Rumex obtusifolius from April to October and cabbage from November to March) were supplied. The mean $( \pm \mathrm{SD}$ ) intake of diets in dry weight ranged from $17.0 \pm 2.2$ to $20.9 \pm 2.7$ $\mathrm{g} / \mathrm{bird} / \mathrm{day}$ for males and from $12.0 \pm 3.4$ to $20.6 \pm 2.6 \mathrm{~g} / \mathrm{birds} / \mathrm{day}$ for females. The energy intake estimated based on diet intake and gross energy in diets ranged from $310.4 \pm 41.2$ to $366.7 \pm 47.9 \mathrm{~kJ} /$ bird/day for males and from $220.7 \pm 63.3$ to $379.2 \pm 48.6 \mathrm{~kJ} / \mathrm{bird} /$ day for females. On the average, both diet and energy intake increased in winters and decreased in summers except for female in May and June. The increased energy intake of females in May might be related to the increased requirements for egg laying and decreased one in June was due to egg incubation. The mean body weight changed seasonally in both sexes, ranging from $344 \pm 7 \mathrm{~g}$ in May to $383 \pm 9 \mathrm{~g}$ in January for males and from $356 \pm 20 \mathrm{~g}$ in June to $412 \pm 31 \mathrm{~g}$ in May for females. The body weights of females were significantly larger than those of males in April and May. The diets used is nutritionally adequate in respect of seasonal changes in body weight which is similar to that in natural conditions. A standard diet for adults birds was presented based on the data for diet intake.

Key Words: Hazel grouse, Tetrastes bonasia, Diet intake, Energy intake, Body weight

帯広畜産大学野生動物管理学研究室ではエゾライチョウ Tetrastes bonasia の人工繁殖 をしており, 成鳥用の飼料として経験的に市販のウズラ用や成彩用の配合飼料と野菜, 一 部の野草を用い, 繁殖期には魚粉などの動物質を添加してきたが (芳賀・鷹股 1986), 与 える餌の内容や量についてはまだ十分に検討されているとはいえず, 決まった給与飼料表 あなかった. 笹岡・藤巻 (1990) は芳賀・鷹股 (1986) による 35 日齢までの幼鳥用の給与 飼料表をあとに, 幼鳥の摂食量を調べて新たに幼鳥用の給与飼料表を作成した. 今回は, 年間を通して成鳥の摂食量と体重の季節変化を調べ, 適切な給与量について検討した. な おこの研究の一部は, 北海道の野生動物分布等実態調査 (北海道保健環境部自然保護課 1993）の一環として行ったものである. 
調查は 1988 年 4-7 月, 1991 年 1 月-1993 年 3 月, 10 月に帯広畜産大学構内の飼育舎 で行った．飼育舎は牛舎の内部を改造し，幅 $1.5 \mathrm{~m}$, 奥行 $3.4 \mathrm{~m}$, 高さ $1.8 \mathrm{~m}$ に金網で区分 したもので, 各ケージの間は床から高さ約 $60 \mathrm{~cm}$ までトタン板で遮蔽し, 内部に常緑針葉 樹の枝を重ねた高さ約 $80 \mathrm{~cm}$ の隠れ場 1 か所, 高さ $50 \mathrm{~cm}$ の台, 止まり木 2 本を設けた. 床には乾燥した砂を深さ $2 \mathrm{~cm}$ ほど敷いた。調查に用いたエゾライチョウの数は, 1988 年 4-7 月には雄 2 羽と雌 3 羽, 1991 年 1 月-1993 年 3 月, 10 月には雄 1-2 羽, 雌 1-3 羽で ある. 前者の場合にはつがい 2 組と雌 1 羽を別々のケージで飼育し, 後者の場合には 1992 年 4 月中旬- 5 月中旬に 1 ケージでつがいとした以外は全て 1 羽づつ飼育した. 調査 期間中の平均気温（飼育施設から約 $100 \mathrm{~m}$ 離れた観測ステーションにおける記録）は, 12 月に $-10^{\circ} \mathrm{C}$ 前後と最む低くなり, 8 月に $18-19^{\circ} \mathrm{C}$ で最も高くなった (Table 1). 飼育舎 の東側と西側の空は常時開いており, 通気がよく, 内部の気温は外気温と変わらない.

餌は, 成鶏用配合飼料 (ホクレンくみあい飼料 $16 \mathrm{~W}$ ), ペットフード (東商トップス), 温水 (ペットフードを軟化させる) を等重量混合したもので（飼料 A)，4-9月にはこの他 に配合飼料の半量の魚粉を加えた (飼料 B). この飼料 $100 \mathrm{~g}$ につきビタミン E 剂 (エーザ イ・ユベラフード $100 ; 1000$ 単位 $/ 1 \mathrm{~g}$ ) $0.1 \mathrm{~g}$, ビタミン A 剂 (エーザイ・チョコラ A 末; 10,000 単位 $/ 1 \mathrm{~g}$ ) $6.3 \mathrm{mg}$, ビタミン D風（エーザイ・チョコラ D 滴；10,000 単位/ $1 \mathrm{ml} ） 1.08 \mathrm{ml}$ を添加した. これを約 $60 \mathrm{~g} /$ 日 /羽与えた. このほか植物繊維質として 410 月にはセイヨウタンポポ, エゾノギシギシ, シロッメクサ, ムラサキッメクサなど, そ れ以外の月にはキャベッを湿重で約 $30 \mathrm{~g} /$ 羽/日与えた. 飼育期間中に秋と冬にそれぞれ 漿果類と冬芽の摂食量を調べた（北海道保健環境部自然保護課 1993）とき以外は, 常に上 記の餌を与えた.このほか水を自由に飲めるようにした (ただし冬には雪を与えた). 給餉 は 1 日 1 回で, 与えた時刻は午後 1-2 時である.

摄食量の測定は数日おきに次の手順で行なった. 飼料之青菜を別々の皿に入れて与え, 24 時間後に残った餌をすべて回収した. 給与量と等量の飼料と青菜, 残った飼料と青菜を $105^{\circ} \mathrm{C}$ (飼料) または $80^{\circ} \mathrm{C}$ (青菜) で 24 時間乾燥してからこれらの重量を別々に測定し, 給与量と残った餌の差を摂食量（乾重, $\mathrm{g} /$ 羽/日；以下同様）とした. なお，4-10月の 青菜の摂食量は, 野草のうちであ好まれるセイヨウタンポポとエゾノギシギシ（藤巻・渡 辺 1993）で調べた. 1988 年には青菜の摂食量を測定しなかった.

青菜を除いた飼料の成分組成と総エネルギーを笹岡・藤巻 (1990)に述べた方法によっ て算出した. 青菜については, 1991 年 6-8月のそれぞれ 20 日ころにセイヨウタンポポと

Table 1. Mean temperatures in the Obihiro University Farm during the study.

\begin{tabular}{rrrrrrrrrrrrr}
\hline \hline & Jan. & \multicolumn{1}{c}{ Feb. } & Mar. & Apr. & May & June & July & Aug. & Sep. & Oct. & Nov. & Dec. \\
\hline 1988 & -9.7 & -10.8 & -3.2 & 4.7 & 9.9 & 15.0 & 14.2 & 19.5 & 14.8 & 7.6 & 0.3 & -3.6 \\
1991 & -5.3 & -9.0 & -1.8 & 6.1 & 12.8 & 17.4 & 17.9 & 18.2 & 16.3 & 10.4 & 2.7 & -3.6 \\
1992 & -10.0 & -7.8 & -1.0 & 5.6 & 10.6 & 14.1 & 18.8 & 19.5 & 14.6 & 9.8 & 2.2 & -4.8 \\
1993 & -7.3 & -6.1 & -1.4 & 4.5 & 10.2 & 13.1 & 16.1 & 18.5 & 15.3 & 8.8 & 3.1 & -3.8 \\
\hline
\end{tabular}


エゾノギシギシをそれぞれ乾重量にして $50 \mathrm{~g}$ 以上を凍結乾燥させ粉砕したすのを冷蔵庫 で保存し,これらを分析して成分組成を求めた. 水分については凍結乾燥後 $125^{\circ} \mathrm{C}$ で 5 時 間乾燥させ恒量を求めた. 灰分については, $550^{\circ} \mathrm{C}$ の電気炉で 5 時間灼熱灰化し恒量を求 めた. 粗脂肪, 全窒素, 粗繊維, 還元糖については, 食品化学実験法 (一之瀬・松永 1975) に従い, それぞれソックスレー抽出法, ケルダール法, 滤過法, BERTRAND 法により求め た. 粗蛋白は全窒素に係数 6.25 を乗じたものとした. $\mathrm{K}, \mathrm{Ca}, \mathrm{Mg}, \mathrm{Na}, \mathrm{Mn}, \mathrm{Fe}, \mathrm{Cu}, \mathrm{Zn}$ につ いては, 原子吸光光度法により求めた. 総エネルギーの求め方は, 上述の飼料の場合と同 じである．キャベッの成分組成は日本食品標準表（科学技術庁資源調查会 1983）に従っ た. 摄取エネルギーは, 飼料と青菜の摂食量にそれぞれの単位乾重当たりの総エネルギー を乗じて算出した. ただし，4,5, 9, 10 月には野草の総エネルギーを測定しなかったので， 4,5 月には 6 月の， 9,10 月には 8 月のそれぞれの野草の総エネルギーの値を用いた.

体重は原則として月に 1 回, さおばかりを用いて $2 \mathrm{~g}$ 単位で計測した.

数值の差の検定には, 雌雄間, 二つの月の間, 青菜の種類間の場合は MANN-WHITNEY の U 検定 (両側)，各月間の場合は KRUSKAL-WALLIS の検定法を用いた。

結 果

\section{1) 飼料之青菜の成分組成}

飼料 B の成分は, 粗蛋白 $21.0 \%$, 粗脂肪 $3.0 \%$, 粗繊維 $2.6 \%$, 粗灰分 $6.6 \%$ で, 総エネ ルギーは, $12.75 \mathrm{~kJ} / \mathrm{g}$, 飼料 A の成分は, 粗蛋白 $13.0 \%$, 粗脂肪 $3.0 \%$, 粗絨維 $3.0 \%$, 粗灰 分 $7.7 \%$ で，総エネルギーは $11.10 \mathrm{~kJ} / \mathrm{g}$ であった (Table 2). セイヨウタンポポの成分組成 は, 水分が $78.2 \sim 83.5 \%$ と高く, 粗蛋白は $0.2 \sim 3.1 \%$, 粗脂肪は $0.5-1.2 \%$, 粗繊維は 1.6 3.3\%，還元糖は 2.3-2.8\%，灰分は 2.0-2.8\%であった (Table 2). ミネラルを灰分 1 $\mathrm{g}$ 当たりで示すと, $\mathrm{Ca}$ が $21.3 \sim 48.9 \mathrm{mg} / \mathrm{g}, \mathrm{Mg}$ が 21.4-25.27 mg/g と多く (Table 2), $\mathrm{Fe}$ は $1.63-5.85 \mathrm{mg} / \mathrm{g}, \mathrm{Mn}, \mathrm{Cu}, \mathrm{Zu}$ は $0.5 \mathrm{mg} / \mathrm{g}$ 以下であった. 総エネルギーは $2.61-3.57 \mathrm{~kJ} / \mathrm{g}$ であった. エゾノギシギシの成分組成は, 水分が 81.0-84.5\% 高く, 粗蛋白は $0.4-4.3 \%$, 粗脂肪は 0.8-1.0\%，粗繊維は 1.3-1.7\%，還元糖は 2.8-4.2\%，灰分は 1.6-2.5\%で，ミネ ラルは 6-7 月にそれぞれ Ca26.2-39.2 mg/g, Mg41.1-61.1 mg/g で多かったが, 8 月に Ca は少なくなった (Table 2). Fe は 2.24-6.31 mg/g で, $\mathrm{Mn}, \mathrm{Cu}, \mathrm{Zn}$ は $0.9 \mathrm{mg} / \mathrm{g}$ 以下であっ た. 総エネルギーは $2.62-3.36 \mathrm{~kJ} / \mathrm{g}$ であった (Table 2). キャベッの成分組成では水分が $92.4 \%$ と多く, ほかの成分が少なく, 総エネルギーは. $1.33 \mathrm{~kJ} / \mathrm{g}$ であった (Table 2).

\section{2) 攝食量}

飼料（青菜を除く）の摂食量は, 雄では 1 月に $19.7 \pm 2.7 \mathrm{~g}$ (平均値士 $\mathrm{SD}$; 以下同様) で あったが，2 月以降次第に減少し，6,7 月にはそれぞれ $14.6 \pm 2.3,14.8 \pm 3.5 \mathrm{~g}$ となり，そ の後また徐々に増加し (Tabel 3), 季節変化を示した $(H=44.37, P<0.01)$. 雌の攝食量も 1 月の $17.9 \pm 2.8 \mathrm{~g}$ からの 6 月の $11.0 \pm 3.5 \mathrm{~g}$ に減少し，その後 12 月の $17.3 \pm 2.1 \mathrm{~g}$ に増加 し (Table 3), やはり季節变化を示した $(H=52.01, P<0.01)$. しかし, 雌では摂食量が 4 月 から 5 月にかけ増加し，6月には著しく減少した点が雄の場合と異なっていた. つがいで

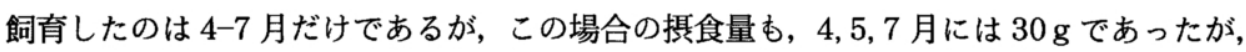
6 月には $21.7 \pm 6.7 \mathrm{~g}$ と少なくなった $(H=17.64, P<0.01)$. 各月で雌雄間の摂食量を比べ 


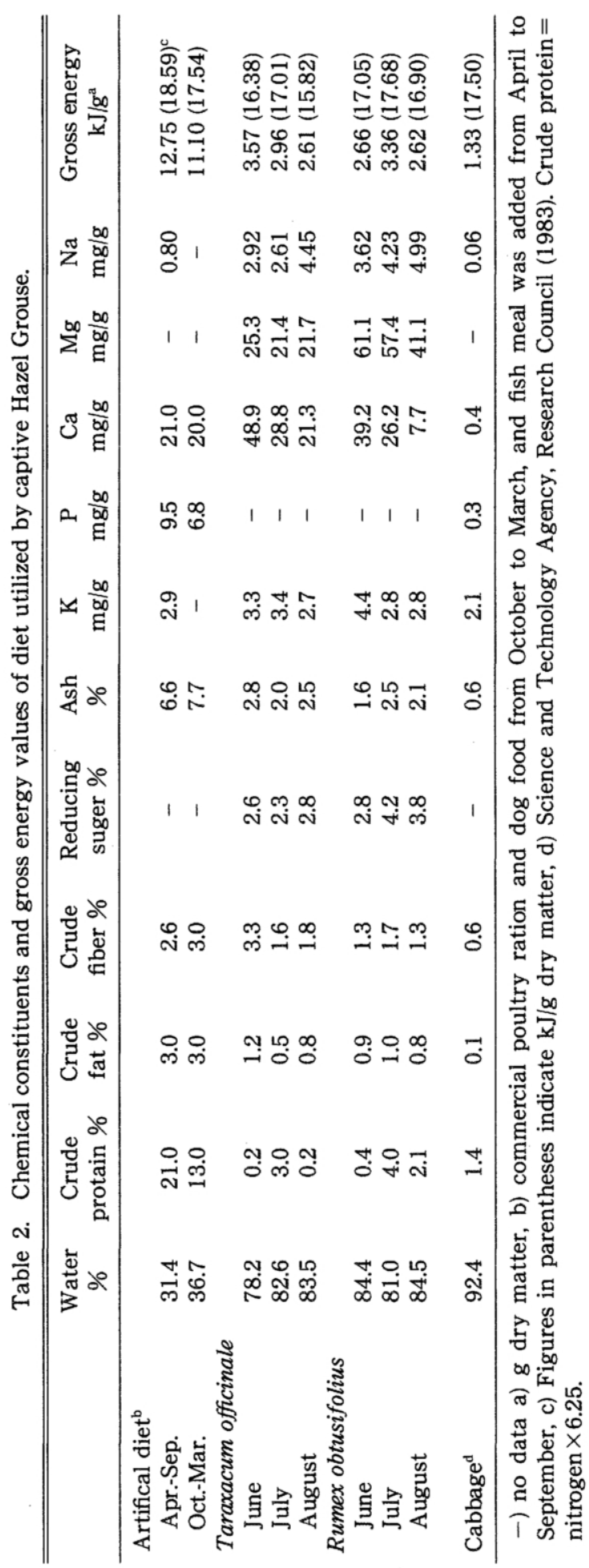


Table 3. Amounts (mean \pm SD) of artificial diet and herb consumed by captive Hazel Grouse in dry weight ( $\mathrm{g} / \mathrm{bird} / \mathrm{day})$.

\begin{tabular}{|c|c|c|c|c|c|c|c|c|}
\hline & \multirow{2}{*}{\multicolumn{2}{|c|}{ Artificial diet }} & \multicolumn{4}{|c|}{ Herb } & \multirow{2}{*}{\multicolumn{2}{|c|}{ Cabbage }} \\
\hline & & & \multicolumn{2}{|c|}{ Taraxacum officinale } & \multicolumn{2}{|c|}{ Rumex obtusifolius } & & \\
\hline & Male & Female & Male & Female & Male & Female & Male & Female \\
\hline Jan. & $19.7 \pm 2.7$ & $17.9 \pm 2.8$ & - & - & - & - & $1.0 \pm 0.2$ & $1.3 \pm 0.5$ \\
\hline Feb. & $19.4 \pm 3.1$ & $18.9 \pm 3.9$ & - & - & - & - & $1.4 \pm 0.5$ & $1.1 \pm 0.4$ \\
\hline Mar. & $18.2 \pm 3.2$ & $17.8 \pm 3.9$ & - & - & - & - & $1.0 \pm 0.4$ & $1.1 \pm 0.4$ \\
\hline Apr. & $15.9 \pm 0.9$ & $15.1 \pm 2.5$ & $1.7 \pm 0.3$ & $1.2 \pm 0.3$ & $2.0 \pm 0.3$ & $1.1 \pm 0.3$ & - & - \\
\hline May & $15.5 \pm 1.5$ & $18.2 \pm 2.8$ & $1.9 \pm 0.5$ & $3.0 \pm 0.7$ & $1.8 \pm 0.4$ & $1.7 \pm 0.4$ & - & - \\
\hline June & $14.6 \pm 2.3$ & $11.0 \pm 3.5$ & $2.4 \pm 0.8$ & $1.1 \pm 0.7$ & $2.2 \pm 0.3$ & $0.4 \pm 0.2$ & - & - \\
\hline July & $14.8 \pm 3.5$ & $15.1 \pm 2.0$ & $2.8 \pm 1.1$ & $2.4 \pm 0.3$ & $2.2 \pm 1.3$ & $2.6 \pm 0.4$ & - & - \\
\hline Aug. & $15.5 \pm 2.5$ & $16.6 \pm 1.7$ & $4.5 \pm 0.9$ & $2.2 \pm 0.6$ & $0.6 \pm 0.1$ & $1.2 \pm 0.6$ & - & - \\
\hline Sep. & $15.7 \pm 1.8$ & $16.0 \pm 1.8$ & $4.1 \pm 0.9$ & $2.9 \pm 0.9$ & $0.5 \pm 0.1$ & $1.1 \pm 0.1$ & - & - \\
\hline Oct. & $16.9 \pm 1.8$ & $16.9 \pm 1.8$ & $2.8 \pm 0.7$ & $2.5 \pm 0.7$ & $0.8 \pm 0.2$ & $1.0 \pm 0.3$ & - & - \\
\hline Nov. & $18.1 \pm 3.6$ & $17.7 \pm 3.6$ & - & - & - & - & $1.1 \pm 0.8$ & $1.2 \pm 0.8$ \\
\hline \multirow[t]{2}{*}{ Dec. } & $18.0 \pm 1.7$ & $17.3 \pm 2.1$ & - & - & - & - & $1.0 \pm 0.5$ & $1.5 \pm 0.6$ \\
\hline & \multicolumn{2}{|c|}{ Pair } & \multicolumn{2}{|c|}{ Pair } & \multicolumn{2}{|c|}{ Pair } & & \\
\hline Apr. & \multicolumn{2}{|c|}{$31.4 \pm 6.3$} & \multicolumn{2}{|c|}{$4.0 \pm 0.7$} & \multicolumn{2}{|c|}{-} & & \\
\hline May & \multirow{2}{*}{\multicolumn{2}{|c|}{$\begin{array}{l}29.8 \pm 4.4 \\
217 \pm 6.7\end{array}$}} & \multicolumn{2}{|c|}{$4.5 \pm 0.8$} & \multicolumn{2}{|c|}{$4.2 \pm 1.7$} & & \\
\hline June & & & \multirow{2}{*}{\multicolumn{2}{|c|}{ - }} & \multirow{2}{*}{\multicolumn{2}{|c|}{ - }} & & \\
\hline July & \multicolumn{2}{|c|}{$27.3 \pm 4.1$} & & & & & & \\
\hline
\end{tabular}

Table 4. Diet items and amount of diets for Hazel Grouse in captivity (wet weight $\mathrm{g} / \mathrm{bird} / \mathrm{day})$.

\begin{tabular}{lccccccc}
\hline \hline \multicolumn{1}{c}{ Seasons } & $\begin{array}{c}\text { Poultary } \\
\text { ration }\end{array}$ & Pet food & $\begin{array}{c}\text { Fish } \\
\text { meal }\end{array}$ & Water $^{\mathrm{a}}$ & $\begin{array}{c}\text { Taraxacum } \\
\text { officinale }^{2}\end{array}$ & Cabbage & Total \\
\hline Apr-Sep. & 12 & 12 & 6 & 12 & 30 & - & 72 \\
(May for female) & 14 & 14 & 7 & 14 & 30 & - & 79 \\
Oct. & 14 & 14 & - & 14 & 30 & - & 72 \\
Nov.-Mar. & 16 & 16 & - & 16 & - & 10 & 58 \\
\hline
\end{tabular}

a) Hot water is used for softening pet food

ると， 6 月には雌の方が少なかったが $(U=48,0.01<P<0.05)$, それ以外の月では有意な差 はなかった（11月 $Z=-0.377$, それ以外の月 $U=7-150, P>0.05$ ).

セイヨウタンポポの摂食量は (Table 3), 雄では 4 月の $1.7 \pm 0.3 \mathrm{~g}$ から次第に増加し, 8 , 9 月にはそれぞれ $4.5 \pm 0.9,4.1 \pm 0.9 \mathrm{~g}$ となり，10月にはやや減少した $(H=25.51, P<$ 0.01). 雌であ摂食量は季節的に变化したが, 5 月に多くなって 6 月に減り, 飼料と同様の 変化であった $(H=26.57, P<0.01)$. エゾノギシギシの攝食量は (Table 3) 雄では 7 月まで は $1.8 \pm 0.4-2.2 \pm 1.3 \mathrm{~g}$ であったが, それ以降には, $0.5 \pm 0.1-0.8 \pm 0.2 \mathrm{~g}$ と少なくなり $(H=22.21, P<0.01)$, 雌では 5 月に増加し， 6 月には減少した $(H=20.54, P<0.01)$ 以外は 各月とあ $1.0 \pm 0.3-1.7 \pm 0.4 \mathrm{~g}$ とほぼ同じ值であった. 8 月の雄, 9,10 月の雌雄ではセイ ヨウタンポポがエゾギシギシより多く摄食されたが $(U=0,0.01<P<0.05)$, それ以外の月 では両種の摂食量には有意な差はなかった $(U=0-27, P>0.05)$. キャベッの摂食量は, 雌 雄とああまり多くなく 1-1.5 g で (Table 3), 月による差あみられなかった $(H=3.54,3.20$, 


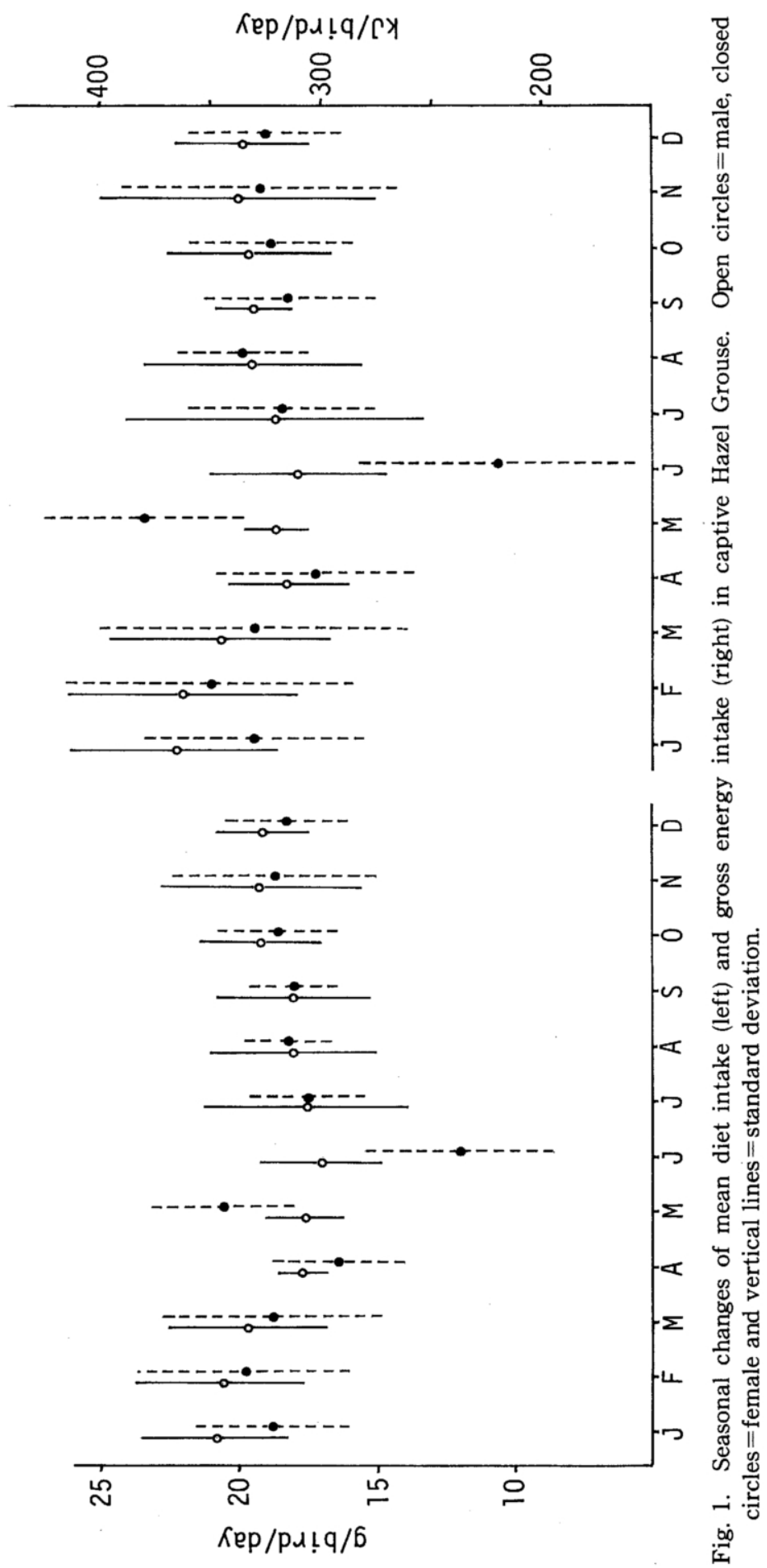


$P>0.05)$. 野草 2 種のつがいの摂食量は 4,5 月の場合しかないが, $4.0 \pm 0.7-4.5 \pm 0.8 \mathrm{~g}$ で (Table 3), 月間であ種類間にも有意な差は認められなかった $(U=9,10, P>0.05)$.

飼料と青菜の摂食量を同時に調べた場合について全摂食量を見ると，雄では 1 月の $20.9 \pm 2.7 \mathrm{~g}$ から 6 月までに $17.0 \pm 2.2 \mathrm{~g}$ に減少し, その後 12 月の $19.1 \pm 1.7 \mathrm{~g}$ まで徐々 に増加した (Fig. 1, $H=22.21,0.01<P<0.05)$. 一方, 雌では 1,2 月の $18.8 \pm 2.8,19.9 \pm$ $3.8 \mathrm{~g}$ から 4 月には $16.4 \pm 2.4 \mathrm{~g}$ に減少したが, 5 月には $20.6 \pm 2.6 \mathrm{~g}$ まで増加し， 6 月には $12.0 \pm 3.4 \mathrm{~g}$ と非常に少なくなり，その後は雄と同様 12 月にかけて徐々に増加した (Fig. $1, H=47.20, P<0.01)$. 各月で雌雄間の摂食量を比べると 5 月には雌の方が雄より有意に 多く $(U=5.5, P=0.05), 6$ 月には反対に雌の方で少なくなったが $(U=26, P<0.01)$, それ以 外の月では有意な差はなかった $(U=5.5-159, P>0.05)$. つがいの摂食量のデー夕は 4,5 月についてしかないが, それぞれ $34.8 \pm 6.0,33.8 \pm 4.4 \mathrm{~g}$ であった.

4-10月に Table 3 に示したような割合で飼料と草本類を摂食した場合, 乾重で草本類 が占める割合は，セイヨウタンポポで 7-23\%, エゾノギシギシで 3-15\%である.

3) 撖取エネルギー

摄取エネルギー（kJ/羽／日；以下同様）は雄では 6 月の $310.4 \pm 41.2 \mathrm{~kJ}$ から 1 月の $366.7 \pm 47.9 \mathrm{~kJ}$ の範囲であったが (Fig. 2)， 月間で有意な差は認められなかった（ $H=$ $16.03, P>0.05)$. 一方, 雌では 5,6 月以外の月では 4 月の $302.8 \pm 45.6 \mathrm{~kJ}$ から 2 月の $363.2 \pm 53.3 \mathrm{~kJ}$ の範囲であったが, 5 月に $379.5 \pm 48.6 \mathrm{~kJ}$ と高くなったあと 6 月には $220.7 \pm 63.3 \mathrm{~kJ}$ と低くなり (Fig. 2), 月によって差が見られた $(H=42.29, P<0.01)$. つが いの場合には 4 月に $640.0 \pm 113.2 \mathrm{~kJ}, 5$ 月に $620.3 \pm 82.4 \mathrm{~kJ}$ であった．各月で雌雄間の 摂食エネルギー量を比べると，摂食量の場合と同様に 5 月に雌の方で多く $U=6$, $P=0.06), 6$ 月には反対に雌で少なく $(U=26, P<0.01)$, それ以外の月には雌雄間で差は認 められなかった $(U=28-119.5, P>0.05)$.

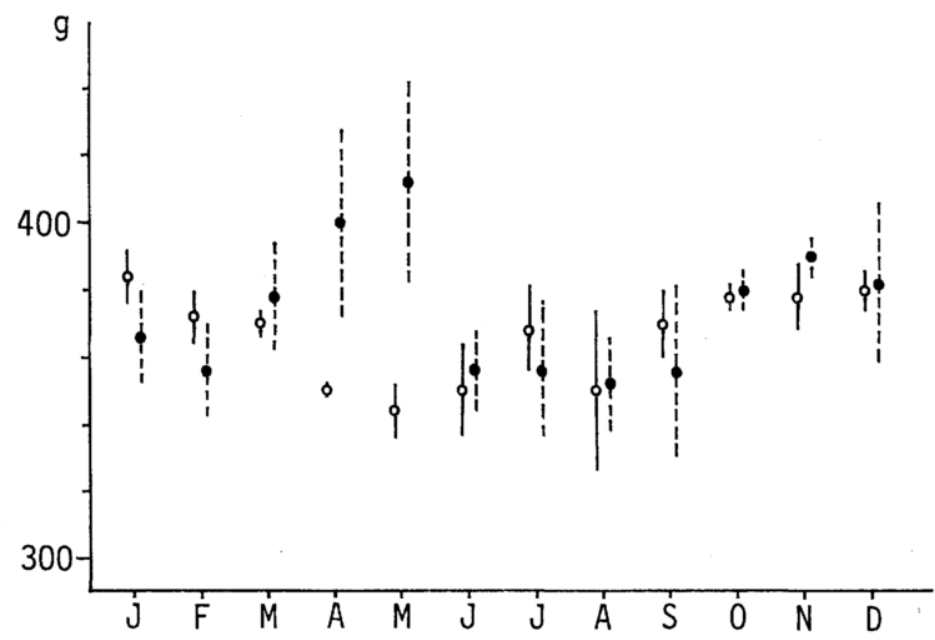

Fig. 2. Seasonal changes of mean body weight of Hazel Grouse. Open circles=male, closed circles $=$ female and vertical lines $=$ standard deviation. 


\section{4) 体重}

雄の平均体重は 1 月に $383 \pm 9 \mathrm{~g}$ で，その後次第に減少し，5 月に最も下がって $344 \pm$ $7 \mathrm{~g}$ となり, それ以降 10 月にかけて徐々に増加して $378 \pm 3 \mathrm{~g}$ となり, 季節変化を示した (Fig. $2, H=22.03,0.01<P<0.05$ ). 雌の平均体重は 1 月に $366 \pm 14 \mathrm{~g}, 2$ 月に $356 \pm 15 \mathrm{~g}$ であったが，その後月ごとに増加し 5 月には $412 \pm 31 \mathrm{~g}$ となり，5月から 6 月にかけて減 少した後は 9 月までほとんど変化せず, 9 月以降に増加して 11 月には $391 \pm 7 \mathrm{~g}$ となった (Fig. 2). 雌の平均体重も季節変化を示したが $(H=26.42, P<0.01)$, 雄の場合と異なり, 4 , 5 月に増加し,この両月の雌の平均体重は雄より有意に大きかった $(U=2(4$ 月 ), 0 (5 月), $0.01<P<0.05)$. それ以外の月には, 雌雄間で平均体重に差は見られなかった $(U=0-10$, $P>0.05)$.

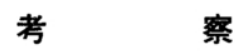

飼料と青菜を併せての平均摂食量には季節変化が見られ, 雌では 5 月に $21.2 \mathrm{~g}$ と多く なり, 6 月に $12.0 \mathrm{~g}$ と少なかったが, それら以外の月では, 4 月の $16.4 \mathrm{~g}$ から 2 月の 19.9 $\mathrm{g}$ まで, 雄では 6 月の $17.0 \mathrm{~g}$ から 1 月の $20.9 \mathrm{~g}$ までの範囲であった. 平均摂取総エネル ギーは，雌で 5 月に $379.2 \mathrm{~kJ}$ と多く，6月に $220.7 \mathrm{~kJ}$ と少なかったのを除くと， 4 月の $302.8 \mathrm{~kJ}$ から 2 月の $363.2 \mathrm{~kJ}$ まで, 雄では 6 月の $310.4 \mathrm{~kJ}$ から 1 月の $366.7 \mathrm{~kJ}$ までの範 囲であった． 5 月に雌の摂食量が多く体重が増加したが，5月中旬一下旬は産卵期にあたっ ているためと考えられる. 飼育下での産卵数は 6-14 卵で（北海道保健環境部自然保護課 1993, 藤巻 未発表), 1 卵の重量は約 $17 \mathrm{~g}$ なので (笹岡 1988), 一腹の総卵重量は 102$238 \mathrm{~g}$ となり，これは雌の体重の 25-54\%に相当する．このような総卵重量の多さが，こ の時期に多くの食物を必要とする理由と考えられる. 雌の攝食量が産卵期に増加すること は，芳賀・鷹股 (1986) であ同様であった．反対に 6 月の摂食量が少なかったのは，6月 上・中旬が抱卵期で, この時期には $96 \%$ の時間を抱卵に費やし, 採餌は 1 日にわずか 2-3 回となるため（北海道保健環境部自然保護課 1993），慨を食べる量が減少するのであろ j.

体重に季節変化があったので, 摂食量を体重 $500 \mathrm{~g}$ 当たりでみると, 6 月の雌で $17 \mathrm{~g}$ と 少なかったほかは, 各月に雌雄とも 24-27 g, 平均 $25 \mathrm{~g}$ であった. ライチョウ Lagopus mutus japonicus を穀類を主とした粗繊維 10\%を含む配合飼料に 10-20\%の粗繊維を加 えた餌で飼育した場合, 攝食量は体重 $500 \mathrm{~g}$ あたり 28- $29 \mathrm{~g}$, 摄取エネルギーは $550 \mathrm{~kJ}$ 前 後であった（唐沢ほか 1989）. またイギリスのヌマライチョウLagopus lagopus の摂食量 は, シチメンチョウ用飼料に 5\%の乾燥ヒース添加した場合には $27-28 \mathrm{~g}, 20 \%$ 添加した 場合には 30-32 g で (Moss \& TRENHOLM 1987), いずれの場合も今回のエゾライチョウよ り多かった. この違いはエゾライチョウで使用した餌の粗戬維が, 摂食した青菜の分を含 めてあ 5-7\%と低かったことが一因と思われる.

この飼料による飼育結果を見ると, 産卵数は非常に小さな卵を産んだ 1 例を除けば 714 卵で, 野外の平均産卵数である 7 卵以上であったし，ふ化率は 63〜92\%, 平均 81\%で （北海道保健環境部自然保護課 1993），野外採取卵のふ化率 93\%（芳賀・鷹股 1986）と比 べてもそれほど低い值ではない. 
体重は, 自然条件では雌雄とも 11-1月に増加し，その後は徐々に減少して，雄では 5 月に最む少なくなり，雌では 5 月に高くなって 6-7 月に少なくなる (SEMENOv-TIANSHANSKy 1959, ANDREEv 1979, DROVETSKIy 1992). 飼育下における体重の季節変化もこ れによく似ていたが, 雄では冬の体重が野外のものより小さかった. すなわち, 北海道各 地で 10-1 月の狩猟期間に捕獲されたエゾライチョウの体重は, 雄で 367-423 g, 平均 $401.3 \pm 21.4 \mathrm{~g}(n=11)$, 雌で 345-423g, 平均 382.2 $223.8 \mathrm{~g}(n=10)$ であったのに対し (藤巻 未発表), 飼育下における同じ時期の平均体重は雌雄ともに $380 \mathrm{~g}$ で, 雌では差が なかったが $(U=63.5, P>0.05), \quad$ 雄の体重は野外のものより平均して $20 \mathrm{~g}$ 少なかった ( $U=26, P<0.01)$.

NAGY (1987) は, 野外で 1 日に必要とするエネルギー $(\mathrm{y}, \mathrm{kJ})$ を体重 $(\mathrm{x}, \mathrm{g})$ から求める式

$$
\log \mathrm{y}=\log \mathrm{a}+\mathrm{b} \log \mathrm{x}
$$

を示した. 非スズメ目鳥類で log a は 0.681 (95\%信頼区間, $0.442 \sim 0.920), \quad \mathrm{b}$ は 0.749 (0.663 0.835) で，これにもとづいてエゾライチョウが必要とするエネルギーを求めると 4-9 月には雄で 391(136-1,123)kJ, 雄で 404(209-1,165)kJ, 10-3 月には雄で 409(141$1,178) \mathrm{kJ}$, 雌で 406(141-1,172) kJ である. また, 体重 $400 \mathrm{~g}$ のエゾライチョウがー $20^{\circ} \mathrm{C}$ と $-40^{\circ} \mathrm{C}$ という条件で 1 日に必要とするエネルギーは,それぞれ $360,376 \mathrm{~kJ}$ である (PoTAPOV \& ANDREEv 1985). また体重 $500 \mathrm{~g}$ 当たりの代謝エネルギーはイギリスのヌマ ライチョウで 307-391 kJ (Moss \& PARKInson 1972), 北アメリカのヌマライチョウで冬 (平均気温-20.4 ${ }^{\circ} \mathrm{C}$ ) に約 $500 \mathrm{~kJ}$ である (WEST 1968). 今回は代謝エネルギーを調べな かったが, 前述のライチョウの場合には代謝エネルギーは 320-350 kJで, 摂取エネル ギーの約 60\%にあたる (唐沢ほか 1989). 纎維質を多く含む食物ほど消化率が低くなるた め(Moss \& TRENHOLM 1987), エゾライチョウで用いた祖瀻維含量の低い餌にライチョウ で得られた値をそのまま適用できないが, 代謝エネルギーは摄取エネルギーより低くなる ので, 今回のエゾライチョウの場合は, NAGY (1987) の式から計算した值や PoTAPOV \& ANDREEV (1985) が示した值, ヌマライチョウの場合より少ないといえる.

以上に述べたように, 繁殖に関しては野外におけるあのと大きな差がなく, 体重の季節 変化む野外のあのと似ていたことを考慮すると, 今回用いた飼料は十分に利用できるもの といえるであろう. しかし，全体に摂取エネルギーは，同様に飼育下で調べた他種のライ チョウ類のものに比べて少なく，雄では冬の体重が野外のものより低かった．これらのこ とから, 摂食量が増加するようにさらに飼料の内容を改良する余地があるだろう.

最後に, ここで得られた乾重摂食量に基づき湿重（乾重の約 1.7 倍）で標準的な給与量 を示す (Table 4). 草本類は最むよく食べられたセイヨウタンポポとし, エゾノギシギシは よく食べられるが, 消化器炎症の原因になる可能性があるため（藤巻・渡辺 1993）用いな いことにした. 飼料の中には必ず食べ残しやこぼすものがあるので, 給与量は与えた量の 80\%が食べられることを想定したあのである.

餌の成分組成分析にご協力いただいた帯広畜産大学環境保全学研究室の福島道広氏にお礼申し上げ る. 
1) 1988 年 4-7 月, 1991 年 1 月-1993 年 3, 10 月にエゾライチョウ成鳥雄 1-2 羽, 雌 1-3 羽を 用いて摂食量を調べた.

2) 飼料は成鷄用配合飼料, ペットフード, 温水を等重量混合したもので， 4-9 月にはこれに魚粉を 1/2 量加えたものである.これに 4-10月にはセイヨウタンポポまたはエゾノギシギシ，11-3月には キャベッを与えた.

3）飼料と青菜の全摂量（乾重）は，雄では $17.0 \pm 2.2$ （6 月） $-20.9 \pm 2.7$ (1 月） g/羽/日で, 冬に多く夏に少なくなる季節变化が見られた．雌では $12.0 \pm 3.4$ (6月) $-20.6 \pm 2.6$ (5月) g/羽／ 日の範囲で, とくに雌では 5 月に多くなり，6月に減少する著しい季節変化が見られた.

4) 摄取エネルギーは，雄では $310.4 \pm 41.2$ (6月) $-366.7 \pm 47.9$ (1月) kJ/羽/日，雌で $220.7 \pm 63.3$ (6 月） $-379.2 \pm 48.6$ (5 月) $\mathrm{kJ} /$ 羽/日で, 摂食量と同様の季節変化が見られた.

5) 平均体重は, 雄では $344 \pm 7$ (5 月) $-383 \pm 9$ (1 月) g の範囲で, 冬に増加し, 夏に減少する 季節変化が見られた，雌では $356 \pm 15$ (2 月） $-412 \pm 31 \mathrm{~g}$ の範囲で, 産卵期にあたる 5 月に最す增 加した.

6) 摂食量に基づく標準的な湿重給与量を，4-10月には飼料 $42 \mathrm{~g}$ とセイヨウタンポポ $30 \mathrm{~g}, 11-$ 3 月には飼料 $48 \mathrm{~g}$ とキャベッ $10 \mathrm{~g}$ とした.

\section{引用 文 献}

ANDREEv, A. V., 1979. Data on winter ecology of grouse in north-east Siberia. "Birds of northeast Asia" (eds. Krechmar, A. V. \& Cherny avsky, F. B.), 27-56, Academy of Sciences of the USSR, Vladivostok. (In Russian).

DRoBEtskiY, S. V., 1992. Materials on ecology of hazel grouse, Tetrastes bonasia, at the south of Magadan district in winter period. Zool. Zhur., 71: 46-59. (In Russian with English summary).

芳賀良一・鷹股修一， 1986. エゾライチョウ Tetrastes bonasia の生態および人工繁殖に関する 研究 I. 繁殖生態, 人工ふ化および飼育管理. 鳥 34: 105-125.

藤巻裕蔵・渡辺美智留， 1993. 飼育下におけるエソライチョウの草本類に対する㖺好性. 日鳥学誌 41:59-63.

北海道保健環境部自然保護課，1993. 野生動物分布等実態調査報告書，エソライチョウ生態等調查報 告書. 札幌, 北海道保健環境部自然保護課.

一之瀨幸男・松井永一, 1975. 食品化学実験法, 三共出版, 東京.

科学技術庁資源調查会, 1983. 日本食品標準成分表. 大蔵省印刷局, 東京.

唐沢豊・崎山千陽・宮野典夫・平林国男・檀原宏，1989. ライチョウによる織維含量の異なる配合飼 料の利用. 家禽会誌 $26: 35-42$.

Moss, R. \& I. B. Trenholm, 1987. Food intake, digestibility and gut size in red grouse. Brit. Poult. Sci. 28: 81-89.

Moss, R. \& J. A. Parkinson, 1972. The digestion of heather (Calluna vulgaris) by red grouse (Lagopus lagopus scoticus). Br. J. Natr. 27: 285-298.

NAGY, K. A., 1987. Field metabolic rate and food requirement scaling in mammals and birds. Ecol. Monog. 57:111-128.

Potapov, R. L. \& A. V. Andreev, 1985. Time and energy budgets in wintering Tetraonidae. Acta XVIII Cong. Intern. Ornithol. 1: 409-412.

笹岡久美子, 1988. エゾライチョウの卵重量係数. 日鳥学誌 37: 84-85.

笹岡久美子・藤巻裕蔵, 1990. エゾライチョウ幼鳥の人工飼料と摂食量. 日鳥学誌，39: 25-32. 
SEmenov-Tian-Shansky, O., 1959. On ecology of tetraonids. Trudy Laplandskogo gosudarstvennogo zapovednika 5: 1-318. (In Russian with English summary).

West G. C., 1968. Bioenergetics of captive willow ptarmigan under natural conditions. Ecol. 1035-1045.

(1994 年 7 月 20 日受理) 